Фармакологічні дослідження біологічно активних речовин Pharmacological researches of biologically active substances

Рекомендована д. біол. наук, проф. Л. С. Фірою

УДК 615.015.35:615.262

DOI 10.11603/2312-0967.2016.3.6821

\title{
ЕКСПЕРИМЕНТАЛЬНЕ ДОСЛІДЖЕННЯ ПІДГОСТРОЇ ТОКСИЧНОСТІ ПРЕПАРАТУ «ДЕРМАБІН»
}

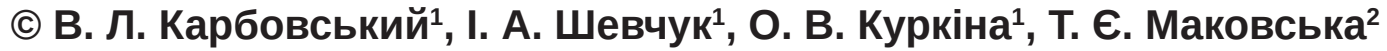 \\ ТОВ «Фармацевтичний завод «Біофрарма», Біла Церква \\ Головний військовий медичний госпіталь², Київ
}

\begin{abstract}
Резюме: встановлено, що препарат «Дермабін» в дозах 500 і 1000 мг/кг за умов щоденного нашкірного нанесення протягом 28 діб не спричиняє загибелі тварин, не чинить токсичного впливу на загальний стан, поведінку, споживання їжі та води, температуру та динаміку маси тіла, абсолютну та відносну масу внутрішніх органів щурів. Результати гематологічних досліджень свідчать, що курсове застосування «Дермабіну» у вищенаведених дозах призводить до розвитку лімфоцитопенії, моноцитопенії, еозинопенії та до незначного збільшення кількості еритроцитів і не змінює кількість тромбоцитів та вміст гемоглобіну в периферичній крові. Показники біохімічних аналізів крові та сечі вказують на те, що «Дермабін» не впливає на білковий, ліпідний, вуглеводний обміни та не порушує роботу гепатобіліарної і сечовидільної систем. Аналіз отриманих даних свідчить про відсутність токсичного впливу препарату «Дермабін» за умов його щоденного нашкірного застосування в надвисоких дозах протягом 28 днів.
\end{abstract}

Ключові слова: підгостра токсичність, бетаметазону дипропіонат, саліцилова кислота, «Дермабін», псоріаз.

Вступ. Одним 3 найбільш поширених хронічних захворювань шкіри, на яке страждає 2-3 \% дорослого населення та 0,5-1 \% дітей, є псоріаз - хронічний рецидивний еритематозно-сквамозний дерматоз мультифракторної природи. Незважаючи на те, що окремі ланки патогенезу цього захворювання досить добре вивчені, а на фрармацевтичному ринку представлено багато доступних методів і засобів лікування, проблема вдосконалення терапії хворих на псоріаз залишається однією з найбільш актуальних у сучасній дерматології [1].

Головною метою лікування $€$ зменшення гостроти та вираженості клінічних об'єктивних і суб'єктивних проявів захворювання, зменшення частоти рецидивів і поліпшення якості життя пацієнтів. Критеріями ефективності лікування $€$ час настання клінічного ефректу, очищення шкіри від висипань, тривалість ремісії, покращення якості життя пацієнта. Не менше значення має високий рівень безпеки, переносимості терапії і зручність ії̈ застосування [2, 3].

В існуючих клінічних рекомендаціях та стандартах надання медичної допомоги хворим на псоріаз різного ступеня тяжкості наведені доказово ефективні групи лікарських засобів: топічні препарати різних класів (зокрема глюкокортикостероїди (ГКС), препарати вітаміну $\mathrm{D}_{3}$ ), фоотосенсибілізуючі засоби для перорального і місцевого застосування при фотохіміотерапії, системні ретиноїди, біологічні препарати, імунодепресанти та цитостатики [4-7]. Серед препаратів із різними хімічними структурами, які представлені на вітчизняному фрармацевтичному ринку, на особливу увагу заслуговує група бетаметазонів. Бетаметазон належить до фрторованих ГКС тривалої дії. Так, за протизапальною активністю він перевершує триамцинолон в 6 разів, при цьому ефективна доза препарату (у ваговому еквіваленті) відповідно в 4-6 разів менше. Швидкість всмоктування топічних ГКС залежить від лікарської фрорми (мазь, крем, лосьйон) і від ліпофрільності. Чим вища остання, тим більша концентрація ГКС створюється в клітинах шкіри і менша в крові. Потрапляючи в дерму, ГКС під впливом естераз піддається діетерифікації з утворенням кінцевих продуктів, які мають високу спорідненість із стероїдними рецепторами. Необхідно зазначити, що цей процес у запаленій шкірі відбувається значно швидше, ніж в здоровій. Таким чином, чим більше виражене запалення, тим швидший і сильніший вплив здійснює бетаметазон [8, 9].

При захворюваннях із вираженими порушеннями кератинізації значно підвищується ефрективність терапії топічними стероїдами в комбінації з кератолітичними засобами - ефективними агентами, які полегшують проникність ліків безпосередньо у вогнище ураження. Комбіновані препарати кортикостероїдів 3 кератолітиками, зокрема з саліциловою кислотою, мають більш виражену терапевтичну дію при псоріазі, ніж кожний препарат окремо [10]. Новий дерматологічний препарат виробництва ТОВ «Фармацевтичний завод «Біофрарма»» - мазь «Дермабін» - містить в своєму складі саліцилову кислоту та бетаметазону дипропіонат. Одним 3 найважливіших етапів розробки безпечних еорективних та конкурентоспроможних

ISSN 2312-0967. Pharmaceutical review. 2016. № 3 
Фармакологічні дослідження біологічно активних речовин Pharmacological researches of biologically active substances

лікарських засобів на стадії доклінічних випробувань $€$ їх токсикологічні дослідження. Тому метою нашої роботи було дослідити підгостру токсичність препарату «Дермабін» при його 28-денному нашкірному застосуванні.

Методи дослідження. Доклінічні дослідження підгострої токсичності препарату «Дермабін» (ТОВ «Фармацевтичний завод «Біофрарма»», м. Біла Церква, Україна, мазь у тубах по 15 г, 1 г якої містить бетаметазону дипропіонат еквівалентно 0,5 мг бетаметазону та кислоту саліцилову 30 мг) проведені на 40 білих нелінійних щурах обох статей масою 170-230 г за умов щоденного нашкірного нанесення на попередньо вистрижені ділянки бокової поверхні тіла (10 \% загальної поверхні тіла) протягом 28 днів [11]. Піддослідних тварин утримували у віварії згідно із стандартними санітарними нормами, на необхідному харчовому раціоні [12]. Усі дослідження виконано згідно з правилами «Європейської конвенції захисту хребетних тварин, які використовуються в експериментальних та інших наукових цілях» [13]. Тварини були розподілені на 3 групи: 1-ша група - інтактний контроль (тварини, яким нашкірно наносили «Вазелін» виробництва ПАТ «Фітофрарм», Україна, в дозі 1000 мг/кг, n=20); 2-га група - тварини, яким нашкірно наносили препарат «Дермабін» в дозі 500 мг/кг, або в перерахунку на діючі речовини - бетаметазону 0,25 мг/кг, саліцилової кислоти 15 мг/кг (умовно терапевтична, яка не викликає будь-яких ознак токсичної дії, n=10); 3-тя група - тварини, яким нашкірно наносили препарат «Дермабін» у дозі 1000 мг/кг, або в перерахунку на діючі речовини - бетаметазону 0,5 мг/кг, саліцилової кислоти 30 мг/кг (субтоксична, n=10). Дані дози відповідають максимальним дозам, які використовували для зовнішнього нанесення при дослідженні субхронічної токсичності оригінального препарату «Діпросалік» (комбінація бетаметазону дипропіонату та саліцилової кислоти) на щурах і кролях [14].

Протягом всього періоду спостереження реєстрували виживання, споживання води і їжі, масу тіла (перед нанесенням препарату, на 7-му, 14-ту, 21-шу, 29-ту доби) та прояви інтоксикації (у разі їх виникнення) за загальним фрізичним станом тварин: зміни положення тіла, активності, поведінки, стану шкірних покривів і слизових оболонок, температури та маси тіла, частоти дихання, а також за окремими симптомами (діарея, сльозоточивість, виділення з носа, тремор, зміна кольору сечі й фрекалій та ін.). У всіх групах тварин після закінчення експерименту (29-та доба) визначали спонтанний добовий діурез, проводили загальноклінічне дослідження крові та сечі [15], після чого, з метою одержання біологічного матеріалу для розрахунку масових коефріцієнтів внутрішніх органів, тварин виводили з досліду шляхом цервікальної дислокації шийних хребців після попередньої наркотизації діетиловим ефіром. Для визначення вихідного рів- ня функціонального стану використовували 10 щурів групи інтактного контролю.

Кількість еритроцитів, лейкоцитів і тромбоцитів крові підраховували в камері Горяєва. Виготовлення і забарвлення мазків, а також визначення фрормули крові проводили відповідно до загальноприйнятих методичних вказівок [16]. Визначення гемоглобіну крові проводили геміхромним методом за допомогою біохімічного аналізатора HTI BioChem SA (Chemistry Analyzer), виробництва High Technology Inc. (США) і стандартного тест-набору виробництва НВП «Філісіт-Діагностика» (Україна). Активність аланінамінотрансорерази (АлАТ), аспартатамінотранссрерази (АсАТ), лужної фросфратази (ЛФ), а також вміст загального білка, альбумінів, глобулінів, креатиніну, сечовини, глюкози, загального холестерину, тригліцеридів, натрію, калію, кальцію, хлоридів, фросфору в сироватці крові визначали за допомогою вищезгаданого біохімічного аналізатора та наборів реагентів для клінічної біохімії виробництва High Technology Inc. (США).

Дослідження загальних властивостей сечі (колір, прозорість, рН, щільність) проводили на 29-ту добу експерименту з використанням стандартних діагностичних тест-смужок DekaPHAN Leuco, виробництва «PLIVA-Lachema Diagnostika» (Чехія). Біохімічний аналіз сечі на вміст загального білка, креатиніну і глюкози проводили на біохімічному аналізаторі НTI BioChem SA (Chemistry Analyzer), виробництва High Technology Inc. (США) з використанням стандартних наборів реагентів для клінічної біохімії виробництва High Technology Inc. (США). Мікроскопію осаду проводили за допомогою світлової мікроскопії.

Статистичну обробку результатів проводили за допомогою пакету прикладних програм STATISTICA 6.0 (StatSoft, USA), використовуючи критерій t Стьюдента та U-критерій Манна-Уітні [17]. Значущими вважали відмінності між контролем і дослідом при р<0,05.

Результати й обговорення. Результати наших досліджень показали, що протягом всього періоду спостереження не реєструвалось загибелі тварин. Стан шкірних покривів, слизових оболонок, споживання води та їжі, температура тіла, активність і положення тіла в усіх дослідних групах не відрізнялись від таких у контрольних щурів. У всіх тварин спостерігався приріст маси тіла без значущих відмінностей між групами. Тобто 28-денне нашкірне нанесення препарату «Дермабін» не справляло негативного впливу на загальний стан, зовнішній вигляд та поведінку щурів.

Порівняльний аналіз показників клінічного аналізу крові на вихідному рівні та після 28-денного застосування «Дермабіну» показав, що курсове нашкірне нанесення препарату в дозах 500 і 1000 мг/кг призводить до помірного зниження кількості лейкоцитів у перифреричній крові дослідних груп щурів на 36,5\% $(p<0,05)$ і 19,7\% (p<0,05) відповідно (табл. 1).

ISSN 2312-0967. Фармацевтичний часопис. 2016. № 3 
Фармакологічні дослідження біологічно активних речовин Pharmacological researches of biologically active substances

Таблиця 1. Деякі показники периферичної крові щурів після 28-денного застосування препарату «Дермабін»

$(\mathrm{M} \pm \mathrm{m})$

\begin{tabular}{|c|c|c|c|c|}
\hline Групи тварин & Гемоглобін, г/л & Еритроцити, 10²/л & Лейкоцити, 10\%/л & Тромбоцити, 10\%л \\
\hline \multicolumn{5}{|c|}{ Вихідні дані } \\
\hline Інтактний контроль & $133,1 \pm 3,02$ & $4,42 \pm 0,05$ & $9,54 \pm 0,48$ & $238,7 \pm 8,24$ \\
\hline \multicolumn{5}{|c|}{$29-$ та доба } \\
\hline Інтактний контроль & $138,7 \pm 4,91$ & $4,39 \pm 0,18$ & $10,71 \pm 0,53$ & $222,5 \pm 7,65$ \\
\hline Дермабін, 500 мг/кг & $148,7 \pm 1,13$ & $4,83 \pm 0,03^{*}$ & $6,80 \pm 0,38^{*}$ & $230,5 \pm 8,28$ \\
\hline Дермабін, 1000 мг/кг & $149,7 \pm 2,13$ & $4,83 \pm 0,07^{*}$ & $8,60 \pm 0,52^{*}$ & $229,5 \pm 11,46$ \\
\hline
\end{tabular}

Примітка. * - p<0,05 щодо інтактного контролю.

В обох дослідних групах відзначено також незначне, проте статистично вірогідне зростання кількості еритроцитів (на 9,1\%; р<0,05) щодо контролю. Вміст гемоглобіну та кількість тромбоцитів при дії «Дермабіну» значущих змін не зазнали (табл.1) і залишались у межах фрізіологічної норми. Визначення морфологічного складу лейкоцитів периферичної крові щурів виявило, що у тварин, яким нашкірно наносили препарат «Дермабін» в дозах 500 і 1000 мг/кг, абсолютна кількість лімфоцитів щодо контролю була меншою на $42,0 \%(p<0,05)$ і 23,5\% (p<0,05), моноцитів - на 47,8 \% $(p<0,05)$ і $29,4 \%(p<0,05)$, еозинофрілів - на 48,4\% $(p<0,05)$ і 41,2 \% $(p<0,05)$ відповідно. Абсолютна кількість всіх фрорм нейтрофрілів у периферичній крові щурів після нанесення препарату, що досліджується, відповідала значенням контрольної групи тварин і знаходилася в межах фрізіологічної норми (табл. 2).
Таким чином, препарат «Дермабін» в дозах 500 і 1000 мг/кг за умов повторних нашкірних нанесень протягом 28-ми діб призводить до розвитку лімороцитопенії, моноцитопенії та еозинопенії, а також до незначного збільшення кількості еритроцитів у перифреричній крові щурів. Кількість тромбоцитів суттєво не змінюється.

Результати дослідження основних біохімічних показників крові щурів, які характеризують фрункціональний стан печінки та нирок, а також вуглеводний та ліпідний обміни, після 28 днів застосування препарату не виявили значущих відмінностей таких показників, як загальний білок, альбуміни, глюкоза, холестерин і тригліцериди (табл. 3). При цьому вміст глобулінів у щурів групи, яка отримувала «Дермабін» у дозі 500 мг/кг, був на 11\% $(p<0,05)$ меншим, ніж у інтактних тварин (табл. 3). Проте ці коливання не ви-

Таблиця 2. Абсолютний вміст різних фрорм лейкоцитів (10\%л) периферичної крові щурів після 28-денного застосування препарату «Дермабін» $(\mathrm{M} \pm \mathrm{m})$

\begin{tabular}{|c|c|c|c|c|c|}
\hline \multirow{2}{*}{ Групи тварин } & \multirow{2}{*}{ Лімсроцити } & \multirow{2}{*}{ Моноцити } & \multirow{2}{*}{ Еозинофріли } & \multicolumn{2}{|c|}{ Нейтрофріли } \\
\hline & & & & паличкоядерні & сегментоядерні \\
\hline \multicolumn{6}{|c|}{ Вихідні дані } \\
\hline Інтактний контроль & $7,43 \pm 0,358$ & $0,462 \pm 0,049$ & $0,208 \pm 0,033$ & $0,131 \pm 0,018$ & $2,28 \pm 0,117$ \\
\hline \multicolumn{6}{|c|}{ 29-та доба } \\
\hline Інтактний контроль & $7,64 \pm 0,439$ & $0,474 \pm 0,052$ & $0,215 \pm 0,037$ & $0,129 \pm 0,016$ & $2,25 \pm 0,110$ \\
\hline Дермабін, 500 мг/кг & $4,43 \pm 0,264^{*}$ & $0,247 \pm 0,031^{*}$ & $0,111 \pm 0,017^{*}$ & $0,101 \pm 0,012$ & $1,91 \pm 0,124$ \\
\hline Дермабін, 1000 мг/кг & $5,84 \pm 0,345^{\star}$ & $0,334 \pm 0,029 *$ & $0,126 \pm 0,014^{*}$ & $0,134 \pm 0,020$ & $2,16 \pm 0,163$ \\
\hline
\end{tabular}

Примітка. * - p<0,05 щодо інтактного контролю.

ходили за межі фрізіологічних норм для даного виду тварин $[18,19]$.

Серед численних біохімічних методів, які застосовують при вивченні нешкідливості хімічних речовин, велике значення надається визначенню активності фрерментів переамінування - АлАТ і АсАТ. Отримані нами результати показали, що курсове нашкірне нанесення щурам препарату «Дермабін» не призводило до зміни активності амінотрансорераз в сироватці крові. Активність ЛФ у щурів дослідних груп також достовірно не відрізнялася від показників у тварин контрольної групи (див. табл. 3).

Нормальну видільну фрункцію нирок підтверджує рівень креатиніну, який характеризувався невеликими коливаннями. Зокрема, в групі тварин, які отримували «Дермабін» в дозі 500 мг/кг, концентрація креатиніну перевищила показник контролю на $10,7 \%(p<0,05)$. Разом 3 тим у тварин, які отримували вищу дозу препарату, статистично вірогідних змін виявлено не було. Слід зазначити, що вміст

ISSN 2312-0967. Pharmaceutical review. 2016. № 3 
Фармакологічні дослідження біологічно активних речовин Pharmacological researches of biologically active substances

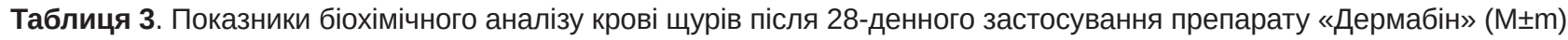

\begin{tabular}{|c|c|c|c|}
\hline \multirow[b]{2}{*}{ Показник } & \multicolumn{3}{|c|}{ Групи тварин } \\
\hline & Інтактний контроль & $\begin{array}{l}\text { Дермабін, } \\
500 \text { мг/кг }\end{array}$ & $\begin{array}{l}\text { Дермабін, } \\
1000 \text { мг/кг }\end{array}$ \\
\hline \multicolumn{4}{|c|}{ Вихідні дані } \\
\hline АлАТ, Од/л & $67,5 \pm 3,58$ & - & - \\
\hline АсАТ, Од/л & $208,7 \pm 9,23$ & - & - \\
\hline ЛФ, Од/л & $280,4 \pm 27,60$ & - & - \\
\hline Креатинін, мг/л & $6,48 \pm 0,11$ & - & - \\
\hline Сечовина, ммоль/л & $10,61 \pm 0,84$ & - & - \\
\hline Загальний білок, г/л & $55,7 \pm 2,18$ & - & - \\
\hline Альбуміни, г/л & $28,8 \pm 1,03$ & - & - \\
\hline Глобуліни, г/л & $28,2 \pm 0,98$ & - & - \\
\hline Глюкоза, ммоль/л & $7,45 \pm 0,37$ & - & - \\
\hline Холестерин, ммоль/л & $1,49 \pm 0,106$ & - & - \\
\hline Тригліцериди, ммоль/л & $0,348 \pm 0,035$ & - & - \\
\hline \multicolumn{4}{|c|}{ 29-та доба } \\
\hline АлАТ, Од/л & $69,6 \pm 3,77$ & $63,6 \pm 5,86$ & $61,8 \pm 6,04$ \\
\hline АсАТ, Од/л & $209,0 \pm 8,81$ & $245,7 \pm 15,69$ & $209,6 \pm 8,58$ \\
\hline ЛФ, Од/л & $272,8 \pm 28,1$ & $318,7 \pm 21,3$ & $248,3 \pm 19,6$ \\
\hline Креатинін, мг/л & $6,59 \pm 0,10$ & $7,30 \pm 0,14^{*}$ & $7,05 \pm 0,26$ \\
\hline Сечовина, ммоль/л & $10,56 \pm 0,80$ & $10,75 \pm 0,74$ & $10,42 \pm 1,07$ \\
\hline Загальний білок, г/л & $56,5 \pm 2,20$ & $52,3 \pm 1,20$ & $53,8 \pm 0,84$ \\
\hline Альбуміни, г/л & $29,2 \pm 1,35$ & $28,0 \pm 0,93$ & $28,4 \pm 0,48$ \\
\hline Глобуліни, г/л & $27,3 \pm 1,06$ & $24,3 \pm 0,50 *$ & $25,3 \pm 0,47$ \\
\hline Глюкоза, ммоль/л & $7,66 \pm 0,49$ & $7,31 \pm 0,35$ & $7,87 \pm 0,28$ \\
\hline Холестерин, ммоль/л & $1,51 \pm 0,131$ & $1,45 \pm 0,080$ & $1,68 \pm 0,122$ \\
\hline Тригліцериди, ммоль/л & $0,359 \pm 0,052$ & $0,394 \pm 0,094$ & $0,257 \pm 0,018$ \\
\hline
\end{tabular}

Примітка. * - p<0,05 щодо інтактного контролю.

цього метаболіту в сироватці крові у всіх групах тварин не виходив за межі фрізіологічної норми, що може свідчити про нормальну екскреторну функцію нирок. Концентрація сечовини (кінцевого продукту метаболізму білків, котрий екскретується нирками) в сироватці крові дослідних груп тварин також достовірно не відрізнялася від контролю і відповідала значенням фрізіологічної норми для щурів (див. табл. 3).

Показники вмісту електролітів ( $\mathrm{Na}+, \mathrm{K}+$, $\mathrm{Ca} 2+$, Cl-, P) не виходили за межі фрізіологічних величин. Хоча слід зазначити, що у тварин, яким наносили «Дермабін» в дозі 500 мг/кг, рівень фосфрору в сироватці крові перевищував показники контролю на $15,4 \%$ ( $<<0,05)$, що становило $(2,66 \pm 0,08)$ ммоль/л проти $(2,31 \pm 0,08)$ у інтактних щурів.

Результати наших досліджень показали, що у тварин, яким протягом 28 діб нашкірно наносили «Дермабіну» у дозах 500 і 1000 мг/кг, істотних змін показників клінічного аналізу сечі, які могли б свідчити про порушення фрункції нирок, не спостерігалося. Так, об'єм сечі, що виділявся, питома щільність та рН у щурів дослідних груп не мали значущих змін щодо відповідних показників у інтактних тварин (табл. 4).

Кількість лейкоцитів у всіх групах була 0-1 в полі зору, еритроцити та гемоглобін не виявлялися. Показники вмісту білка, креатиніну і глюкози в групах щурів, яким наносили «Дермабін», статистично не відрізнялися від таких у контрольній групі тварин. Таким чином, субхронічне застосування препарату «Дермабін» в дозах 500 і 1000 мг/кг не призводять до порушення фрункціонального стану нирок піддослідних тварин.

Встановлено, що тривале нашкірне нанесення досліджуваного препарату «Дермабін» в дозах 500 і 1000 мг/кг протягом 28 діб не призводить до істотної зміни маси внутрішніх органів. Показники коеоріцієнтів маси внутрішніх органів тварин дослідних груп, а також контрольної групи (табл. 5) перебували в межах фрізіологічної норми [18].

ISSN 2312-0967. Фармацевтичний часопис. 2016. № 3 
Фармакологічні дослідження біологічно активних речовин Pharmacological researches of biologically active substances

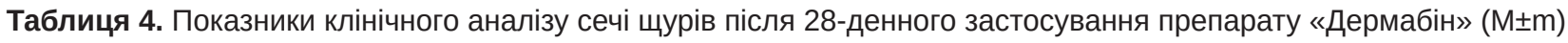

\begin{tabular}{|c|c|c|c|}
\hline \multirow[b]{2}{*}{ Показник } & \multicolumn{3}{|c|}{ Групи тварин } \\
\hline & Інтактний контроль & $\begin{array}{l}\text { Дермабін, } \\
500 \text { мг/кг }\end{array}$ & $\begin{array}{l}\text { Дермабін, } \\
1000 \text { мг/кг }\end{array}$ \\
\hline \multicolumn{4}{|c|}{ Вихідні дані } \\
\hline Діурез, мл/добу & $4,52 \pm 0,30$ & - & - \\
\hline Питома щільність & $1,019 \pm 0,002$ & - & - \\
\hline $\mathrm{pH}$ & $7,08 \pm 0,28$ & - & - \\
\hline Гемоглобін & не виявл. & - & - \\
\hline Еритроцити & не виявл. & - & - \\
\hline Лейкоцити & $0-1$ & - & - \\
\hline Білок, г/л & $2,75 \pm 0,18$ & - & - \\
\hline Глюкоза, ммоль/л & $0,170 \pm 0,018$ & - & - \\
\hline Креатинін, мг/л & $274,2 \pm 22,3$ & - & - \\
\hline \multicolumn{4}{|c|}{ 29-та доба } \\
\hline Діурез, мл/добу & $4,53 \pm 0,34$ & $4,50 \pm 0,24$ & $4,50 \pm 0,30$ \\
\hline Питома щільність & $1,018 \pm 0,003$ & $1,020 \pm 0,002$ & $1,020 \pm 0,002$ \\
\hline $\mathrm{pH}$ & $7,15 \pm 0,31$ & $6,90 \pm 0,21$ & $6,65 \pm 0,18$ \\
\hline Гемоглобін & не виявл. & не виявл. & не виявл. \\
\hline Еритроцити & не виявл. & не виявл. & не виявл. \\
\hline Лейкоцити & $0-1$ & $0-1$ & $0-1$ \\
\hline Білок, г/л & $2,81 \pm 0,19$ & $2,68 \pm 0,22$ & $2,56 \pm 0,24$ \\
\hline Глюкоза, ммоль/л & $0,169 \pm 0,017$ & $0,182 \pm 0,020$ & $0,173 \pm 0,021$ \\
\hline Креатинін, мг/л & $272,1 \pm 21,5$ & $288,2 \pm 20,7$ & $297,8 \pm 25,6$ \\
\hline
\end{tabular}

Примітка. * - p<0,05 щодо інтактного контролю.

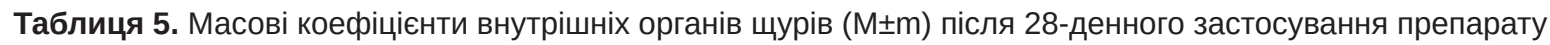
«Дермабін»

\begin{tabular}{|c|c|c|c|c|}
\hline \multirow{2}{*}{ Орган } & \multicolumn{3}{|c|}{ Умови досліду } \\
\cline { 2 - 4 } & Інтактний контроль & $\begin{array}{c}\text { Дермабін, } \\
500 \text { мг/кг }\end{array}$ & $\begin{array}{c}\text { Дермабін, } \\
1000 \text { мг/кг }\end{array}$ \\
\hline \multicolumn{2}{|c|}{ Головний мозок } & $0,582 \pm 0,023$ & $0,565 \pm 0,013$ & $0,574 \pm 0,032$ \\
\hline \multirow{2}{*}{ Пирки } & Ліва & $0,381 \pm 0,008$ & $0,365 \pm 0,005$ & $0,353 \pm 0,017$ \\
\cline { 2 - 5 } & $0,382 \pm 0,006$ & $0,366 \pm 0,006$ & $0,353 \pm 0,014$ \\
\hline \multicolumn{2}{|c|}{ Серце } & $0,354 \pm 0,009$ & $0,362 \pm 0,010$ & $0,348 \pm 0,011$ \\
\hline \multicolumn{2}{|c|}{ Легені } & $0,705 \pm 0,030$ & $0,718 \pm 0,023$ & $0,716 \pm 0,020$ \\
\hline \multicolumn{2}{|c|}{ Печінка } & $3,23 \pm 0,164$ & $3,34 \pm 0,121$ & $3,11 \pm 0,101$ \\
\hline \multicolumn{2}{|c|}{ Селезінка } & $0,428 \pm 0,030$ & $0,439 \pm 0,024$ & $0,448 \pm 0,031$ \\
\hline
\end{tabular}

Висновки. 1. Препарат «Дермабін» у дозах 500 і 1000 мг/кг за умов щоденного нашкірного нанесення протягом 28 діб не викликає загибелі тварин, не чинить токсичного впливу на загальний стан, поведінку, споживання їжі та води, приріст маси тіла, абсолютну та відносну масу внутрішніх органів щурів.

2. Курсове застосування «Дермабіну» в дозах 500 і 1000 мг/кг призводить до розвитку лімфроцитопенії, моноцитопенії, еозинопенії та до незначного збільшення кількості еритроцитів і не впливає на кількість тромбоцитів та вміст гемоглобіну в периферичній крові.

3. Дермабін не впливає на білковий, ліпідний, вуглеводний обміни та не порушує роботу гепато-біліарної і сечовидільної систем.

ISSN 2312-0967. Pharmaceutical review. 2016. № 3 
Фармакологічні дослідження біологічно активних речовин Pharmacological researches of biologically active substances

\section{Список літератури}

1. Dubertret L. Psoriasis: evolution and revolution / L. Dubertret // Med. Sci. - 2006. - Vol. 22. - P. 164-171.

2. Псориаз. Клинические рекомендации / под ред. А. А. Кубановой. - М. : ДЭКС-Пресс, 2008. - 56 с.

3. T-helper 22 cells as a new player in chronic inflammatory skin disorders / A. Mirshafiey, A. Simhag, N. M. El Rouby, G. Azizi // Int. J. Dermatol. - 2015. - Vol. 54(8). - P.880-888.

4. Дядык Е. А. Влияние узкополосной (311 нм) ультрафиолетовойтерапии на клинико-морфологичекую структуру кожи больных вульгарным псориазом / Е. А. Дядык, И. О. Жданова // Укр. журн. дерм. венер. космет. - 2015. - № 4(59). - С. 44-50.

5. Асцатуров Г. Є. Клініко-імунологічне обґрунтування есрективності мазі кальцитріолу у лікуванні хворих на псоріаз / Г. Є. Асцатуров, Ю. В. Андрашко, О. І. Літус // Укр. журн. дерм. венер. космет. - 2008. - № 4. - С. 2426.

6. Степаненко Р. Л. Структурні зміни в ділянках шкірної псоріатичної висипки після проведення системної імуносупресивної терапії / Р. Л. Степаненко, С. Г. Гичка, Муїн Тусрфаха // Укр. журн. дерм. венер. космет. - 2015. - № 2. - C. 30-36.

7. Biological therapies in the systemic management of psoriasis: International Consensus Conference / W. Sterry, J. Barker, W. H. Boehncke [et al.] // Br. J. Dermatol. - 2004.

- Vol.151, Suppl. 69. - P. 3-17.

8. Коляденко В. Г. Комбинированные препараты группы бетаметазона в лечении аллергодерматозов / В. Г. Коляденко, П. В. Чернышов // Укр. журн. дерм. венер. космет. - 2007. - № 1. - С. 31-34.

9. Мурзина Э. А. Современные подходы к выбору идеального топического кортикостероида / Э. А. Мурзина // Мистецтво лікування. - 2009. - № 7 (63). - C. 46-49.

10. Elie R. Effect of salicylic acid on the activity of betamethasone-17,21-dipropionate in the treatment of erythematous squamous dermatoses / R. Elie, L. P. Durocher, E. C. Kavalec // J. Int. Med. Res. - 1983. Vol. 11(2). - P. 108-112.

11. Доклінічні дослідження лікарських засобів: методичні рекомендації / за ред. О. В. Стефанова. - К. : Авіцена, 2001 p. -528 c.

12. Стефранов О., Бухтіарова Т., Коваленко В. та ін. Настанова СТ-НМОЗУ 42-6.0:2008. Лікарські засоби. Належна лабораторна практика (видання офріційне). K. : Моріон, 2009. - C.37-68.

13. European convention for the protection of vertebrate animals used for experimental and other scientific purpose: Council of Europe 18.03.1986. - Strasbourg, 1986. - 52 p. 14. Product Monograph. DIPROSALIC ${ }^{\circledR}$ Lotion and Ointment (Betamethasone Dipropionate and Salicylic Acid). Topical Corticosteroid and Keratolytic. - Merck Canada Inc., Date of Preparation: 07.02.2011. - 16 p.

15. Оптимизация условий исследования фрункций почек в хроническом експерименте / Э. Ф. Баринов, А. Г. Кот, Е. Д. Якубенко, Л. А. Буряк // Физиологический журнал. - 1987. - Т. 33, № 6. - С. 80-82.

16. Лабораторные исследования в клинике / под ред. В. В. Меньшикова - М. : Медицина, 1987. - 365 с.

17. Реброва О. Ю. Статистический анализ медицинских данных. Применение пакета прикладных программ STATISTICA / О. Ю. Реброва. - 3-е изд. - М. : МедиаСорера, 2006. - 312 с.

18. Проблема нормы в токсикологии. (Современные представления и методические подходы, основные параметры и константы) / под ред. профр. И. М. Трахтенберга. - М. : Медицина, 1991. 204 c.

19. Sharp P. E. The Laboratory Rat / P. E. Sharp, M. C. La Regina. - CRC Press, 1998. -240 p.

\section{ЭКСПЕРИМЕНТАЛЬНОЕ ИССЛЕДОВАНИЕ ПОДОСТРОЙ ТОКСИЧНОСТИ ПРЕПАРАТА «ДЕРМАБИН»}

\section{В. Л. Карбовский', И. А. Шевчук ${ }^{1}$, О. В. Куркина ${ }^{1}$, Т. Е. Маковская ${ }^{2}$}

ООО «Фармацевтический завод «Биофрарма», Белая Церковь

Главный военный медицинский госпиталь², Киев

Резюме: установлено, что препарат «Дермабин» в дозах 500 и 1000 мг/кг при его ежедневном накожном нанесении в течение 28 дней не вызывает гибели животных, не оказывает токсического влияния на общее состояние, поведение, потребление пищи и воды, температуру и динамику массы тела, абсолютную и относительную массу внутренних органов крыс. Результаты гематологических исследований свидетельствуют о том, что курсовое применение «Дермабина» в вышеупомянутых дозах приводит к развитию лимфоцитопении, моноцитопении, эозинопении, а также к незначительному увеличению количества эритроцитов, при этом не изменяя количество тромбоцитов и содержание гемоглобина в периферической крови. Показатели биохимических анализов крови и мочи указывают на то, что «Дермабин» не влияет на белковый, липидный, углеводный обмены и не нарушает работу гепатобилиарной и мочевыделительной систем. Анализ полученных данных свидетельствует об отсутствии токсического влияния препарата «Дермабин» при его ежедневном накожном нанесении в сверхвысоких дозах в течение 28 дней.

Ключевые слова: подострая токсичность, бетаметазона дипропионат, салициловая кислота, «Дермабин», псориаз.

ISSN 2312-0967. Фармацевтичний часопис. 2016. № 3 
Фармакологічні дослідження біологічно активних речовин

Pharmacological researches of biologically active substances

\title{
EXPERIMENTAL STUDY OF SUBACUTE TOXICITY OF «DERMABIN»
}

\author{
V. L. Karbovskyi ${ }^{1}$, I. A. Shevchuk ${ }^{1}$, O. V. Kurkina ${ }^{1}$, T. Ye. Makovska ${ }^{2}$ \\ Ltd. "Pharmaceutical Plant "Biofarma", Bila Tserkva" \\ Main Military Medical Hospital, Kyiv²
}

Summary: it has been established that Dermabin in doses of 500 and $1000 \mathrm{mg} / \mathrm{kg}$ applied epicutaneously daily during 28 days does not cause death of animals, has no toxic effect on the overall condition, behavior, consumption of food and water, body temperature and mass dynamics, absolute and relative mass of internal organs of rats. According to hematological studies, a protracted treatment by Dermabin in the above doses results in the development of lymphocytopenia, monocytopenia, eosinopenia and slight increase in RBC count and does not change platelet count and hemoglobin content in peripheral blood. Blood and urine chemistry tests indicate that Dermabin has no effect on the protein, lipid, carbohydrate metabolism and does not disrupt the function of the hepatobiliary and urinary systems. Data analysis indicates that Dermabin has no toxic effect if applied daily on the skin in very high doses during 28 days.

Key words: subacute toxicity, betamethasone dipropionate, salicylic acid, Dermabin, psoriasis.

Отримано 01.06.2016

ISSN 2312-0967. Pharmaceutical review. 2016. № 3 